\title{
Biological activity of propolis: an update
}

\author{
Soltani $\mathbf{A}^{1}{ }_{\mathrm{z}}$ Benhanifia $\mathbf{M}^{2^{*}}$
}

\footnotetext{
${ }^{1}$ Department of biology, Faculty of Natural and Life Sciences, University Mustapha Stambouli of Mascara, 29000 Mascara, Algeria.

* Department of Agricultural Science, Faculty of Natural and Life Sciences, University Mustapha Stambouli of Mascara, 29000 Mascara, Algeria Author corresponding: e-mail:benhanifia@gmail.com, mokhtar.benhanifia@univ-mascara.dz

Tel: +213542680644， +213655151564
}

\begin{abstract}
Antibiotic resistance was described soon discovery of penicillin by Fleming. In recent years, there has been increasing research interest in the development of alternatives to address this problem. Natural products, mainly, have long been considered as sources of drugs, and a great part of pharmaceuticals available in modern medicine are directly or indirectly derived from natural sources.

propolis been used to treat human diseases since ancient times, propolis, is a natural resinous mixture produced by honeybees (Apis mellifera) from collected parts of plants, he is increasingly recognized by their wide range of biological and pharmacological properties, As anti- infective agent, combination synergy with standard antibiotics could be very promising alternative strategy.
\end{abstract}

Keywords: bee propolis; biological activity; antibacterial

\section{Introduction}

Antimicrobial resistance has been a growing concern worldwide [1]. It has been defined as a global pandemic for the twenty-first century in [2], Recently, World Health Organization (WHO) has released a list (12 bacteria names from bacterial families) of the drug-resistant bacteria that pose a big sanitary challenges to human health $[4,5]$, such problem is due to the lack of effective surveillance measures and widespread overuse,

In the 1990s a sharp reduction in development of new drug classes coupled with emergence of strains of human pathogens resistant with a great concern are multi-drug-resistant strains., now antimibrobial resistance causes 700,000 or more deaths each year which number could grow to 10 million by 2050 $[4,6]$,with a loss of up to USD100 trillion to the global economy[7]. 
In the USA, the prevalence of antimicrobial resistance has increased markedly in recent years, For example, methicillin-resistant Staphylococcus aureus (MRSA), In 1999, MRSA accounted for more than $50 \%$ of S. aureus isolates from patients in Intensive Care Units (ICUs) in the National Nosocomial Infection Surveillance (NNIS) system; in 2003, 59.5\% of S. aureus isolates in NNIS ICUs were MRSA. Moreover, Antibiotic resistant Mycobacterium tuberculosis strains was reported, WHO estimates that, in 2018, there were about half a million new cases of rifampicin-resistant tuberculosis (TB) identified globally, of which the vast majority have multi-drug resistant TB (MDR-TB), a form of tuberculosis that is resistant to the two most powerful anti-TB drugs(https://www.who. int/news-room/fact-sheets/detail /anti microbial resistance).

A similar increase in prevalence has occurred in vancomycin-resistant enterococci (VRE). VRE causes nosocomial infections, and can also be transmitted from animals through ingestion or direct contact[3]. Emergence of antimicrobial resistance bacteria has human health consequences. Such consequences include increased frequency of treatment failures and increased severity of infection. The latter includes prolonged duration of illness, increased frequency of bloodstream infections, increased hospitalisation and increased mortality [8]..

It is clear that the need for new antibiotics is greater than ever before, because of the emergence of multi-drug-resistant and pan-resistant pathogenic microorganisms, paradoxically, despite the clinical need for new antimicrobial agents, the development of these agents is declining. Since the 1970s, few new antibiotics have been discovered, and $[3,6]$. It has been reported that, costs for pharmaceutical research and development, are estimated about $\$ 800$ to $\$ 900$ million and 10 to 15 years per approved agent (Monnet, 2005) in [3]. This may explain why the pharmaceutical industry currently concentrates on the development of analogs. However, the numbers of analogues which can be made from a single chemical core are limited and bacteria can develop resistance to new analogs and consequently more loss of antibiotic class efficacy [9]. In other hand, overuse, inappropriate use of antimicrobial or other factor like certain environmental conditions (for example; body compartments where antibiotic has a difficult access) can exacerbate resistance problem [10].

More recently, concerns have arisen over the extensive nontherapeutic antimicrobial (NTA) use. In the United States it was estimated to be equal to (WHO,1997) or eight times greater than the quantity administered for therapeutic use. NTA uses are also linked to the propagation of multidrug resistance (MDR), including resistance against drugs that were never used on the farm [11].

In other hand, It has been demostrated that bactericidal antibiotics induce the formation of toxic reactive oxygen species (ROS) both in bacteria and mammalian cells. antibiotics such as, quinolones, aminoglycosides, and $\beta$-lactams cause mitochondrial dysfunction and ROS overproduction in cells thus, can lead to oxidative tissue damage [12].Such imbalance increases the 
damage to the biomolecules, such as proteins, lipids, DNA, and sugars $[12,13$, 14].

Finally, antimicrobial resistance represent multifactorial problems that must be addressed from different disciplines, including Medicine, Genetics, Microbiology, Epidemiology and Sociology [10].

In recent years, there has been increasing research interest in the development of alternatives to address this problem. Propolis or bee glue, as it is commonly named, is a natural resinous mixture produced by honeybees (Apis mellifera) from substances collected from parts of plants, buds and exudates [17].This resin is masticated, salivary enzymes are added, and then it is mixed with beeswax and probably with other compounds of bee metabolism [18]. Once collected by honey bees, this material is modified and mixed with wax and enzymatic secretions. The resulting substance is used by bees to seal holes in their hives and strengthen the thin borders of the comb. Propolis in the hive also acts as a biocide, and may have activity against invasive bacteria, fungi and even invading larvae $[19,20,21]$. Propolis is increasingly recognized by their wide range of biological and pharmacological properties, with many useful application in medicines and cosmetics, food industries, packaging and animal husbandry[22], The activity of propolis, including antibacterial [17,23,24, $25,26,27,28]$, Antiviral [29], Antifungal [30], antioxidant [31, 32], immunostimulatory, anti-inflammatory $\quad[28,33]$ and cytostatic effects [18].

\section{Propolis :}

The word "propolis" derives from Hellenistic Ancient Greek (suburb, bee glue) and describes the role of propolis to cement openings of the bee hive. Propolis is also "pro» = in front, «polis» = city, which means hive defensive substance [34] The meaning in front of the city suits well the protecting role of propolis for the bee colony [35,36]. Propolis has been used by humans as a traditional in folk medicine to maintain good health since ancient times by many civilizations; Egyptians, Arabs, Greek, Roman and many other civilizations [37]. Egyptians knew very well its anti-putrefactive properties and used bee glue to embalm their cadavers. Incas employed propolis as an anti-pyretic agent. Greek and Roman physicians used it as mouth disinfectant and as an antiseptic and healing product in wound treatment, skin abscesses, prescribed for topical therapy of cutaneous and mucosal wounds [38]. These therapeutic applications were perpetuated in the Middle Age and among Arab physicians. They described medicinal preparations containing propolis which was used for treatment of dental caries, oral and pharyngeal infections [36].

In the end of $19^{\text {th }}$ century, propolis was widely used due to its healing properties, in the Second Global War it was employed in several Soviet clinics for tuberculosis treatment, due to the observed decline of lung problems and appetite recovery, it has been called "Russian penicillin" [39]. In the Balkan states it was one of the most frequently used remedies, applied to treat wounds and burns, sore throat and stomach ulcer [40]. 


\subsection{Plant Sources of propolis}

Propolis is an important product of the hive, collected by the bees from living plants, particularly from flowers and leaf buds.which is mixed with various amounts of beeswax and resins, used as building and protective material against insects and pathogenic organisms [21].

according to the botanical source, its color varies from yellow-green, to red and to dark brown depending on its source and age. But, even transparent propolis has been reported by $[19,20]$.

Many studies on the properties and composition of propolis have been made without knowing the plant(s) from which the sample was obtained, or the sites where bees collected the material. However, phytochemical composition is complex and highly variable, depending on the season and available flora at the site of collection [41,42].

The source species can vary with geographical regions and chemical compositions of propolis, as shown in (Figure.1) different types of propolis are available worldwide [38,43,44,45]:

i) European propolis (Poplar type (Populus spp. which is originate mainly from Europe, non-tropic regions of Asia, New Zealand and North America), ii) Birch type or Russian propolis (Betula verrucosa which is derived from Russia), iii) Green type or green Brazilian propolis (South-eastern and western-central Brazil; derived from Baccharis spp.) iv) Red type or red Brazilian propolis (derived from Dalbergia spp. which is located in north-eastern part of Brazil,, Mexico and Cuba), v) Clusia type (from Clusia spp. From Cuba and Venezuela) and vi) Pacific type (Macaranga tanarius which is originate from Indonesia, Taiwan and Okinawa Prefecture) and vii) the most recent, Mediterranean type (plants mainly from Cupressaceae family which is located in Greece, Sicily and Malta. "Canarian" propolis (plant origin unknown), etc..

Many other works, reported that in temperate zones the bud exudates of Populus species and their hybrids are the main source of bee glue. In China, besides the main source poplar [46]: bees also use pines, cypress, willow and sumacs $[34,47,48]$. In Turkey, poplar seems to be the main origin, however other plant sources of bee glue is collected from pine trees, eucalyptus and castanea $[49,50,51,52,53,54]$.

In tropical regions, other plant source of bee glue is collected. The most popular propolis type, the green Brazilian propolis(GBP), originates from the leaves of wild rosemary; Baccharis dracunculifolia (Asteraceae) [55, 56,57].

be the main origin, however other plant sources of bee glue is collected from pine trees, eucalyptus and castanea $[49,50,51,52,53,54]$.

In tropical regions, other plant source of bee glue is collected. The most popular propolis type, the green Brazilian propolis(GBP), originates from the leaves of wild rosemary; Baccharis dracunculifolia (Asteraceae) [55, 56,57]. 


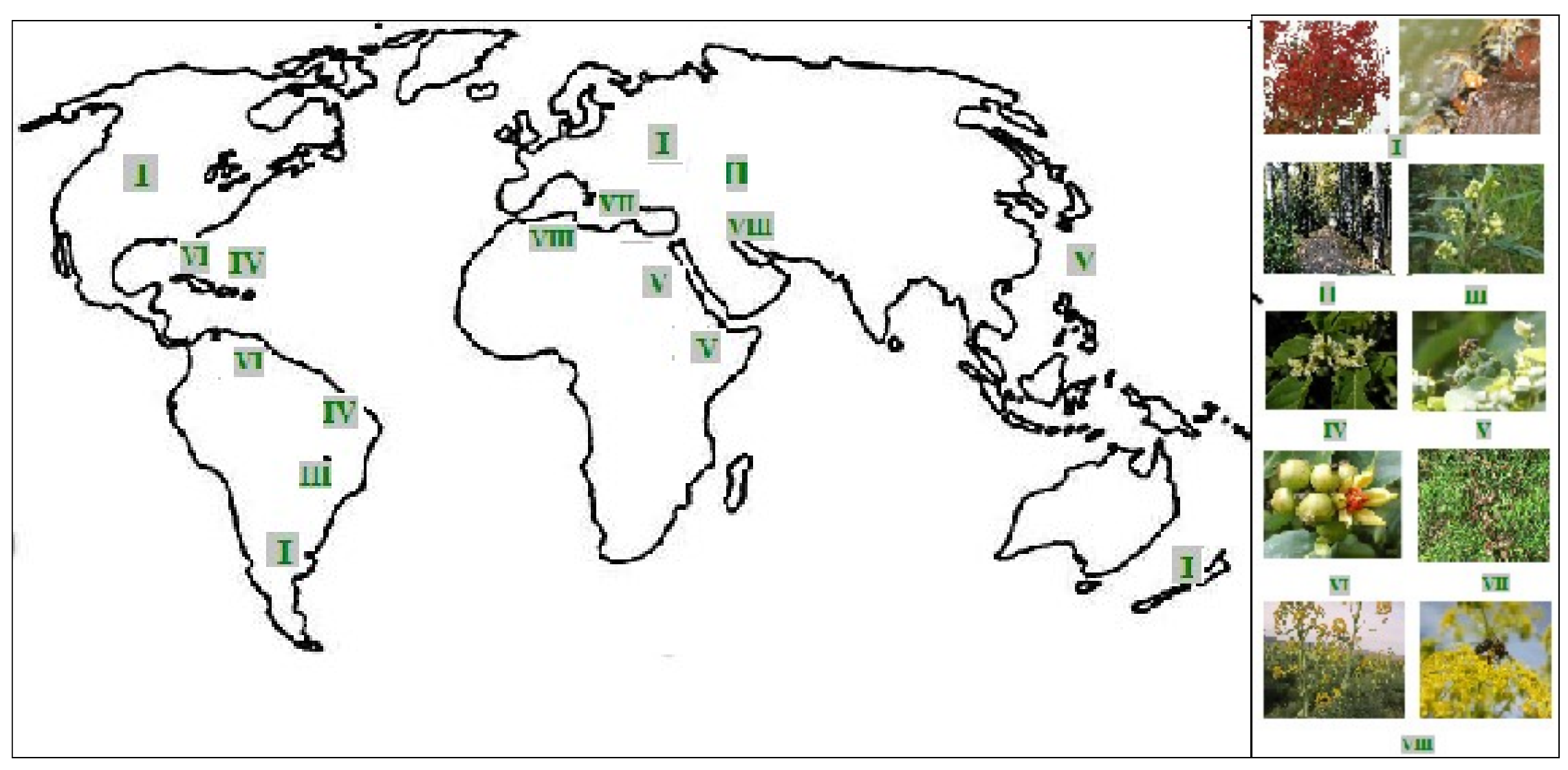

Figure. 1. Distribution of some propolis types.I- temperate poplar propolis,:http://beespoke.info/2015/10/20/bee-trees-poplar-populus-spp/.II- Birch type or Russian propolis.https://fr.wikipedia.or g/wiki /Bouleau verruqueux \#/media/Fichier:Birch walk Weilerbach Luxembg 01.jpg III-Brazilian green propolis,: derived from the buds of Baccharis dracunculifolia DC . IV- Red type or red Brazilian propolis(derived from Dalbergia spp. https://eol.org/pages/639535. V- Pacific type (derived from Macaranga tanarius [58]. VI-Clusia type (from Clusia spp.https://www.pronativascr.org/plantas/clusia-spp/) VII-Mediterranean type (plants from Cupressaceae family. https://fr.wikipedia.org/wiki/Cupressaceae). .VIII-Iranian propolis, Algerian propolis (derived from Ferula spp https:// fr. wikipedia.org wiki/Fichier: erula communis03.jpg). 
Other type of propolis found Brazilian, Cuban and Mexican regions called red propolis, which bees collect vegetable material (Figure. 2) (red resinous exudates from plants; Dalbergia species (Fabaceae)) (Figure. 4) [57,59, 60].

In tropical islands in the Pacific Ocean (Taiwan, Okinawa, Indonesia), there is a specific propolis type, designated sometimes as "Pacific propolis". It contains prenylated flavanones (propolins) as major constituents [58,61,62,63] and its plant source is the resin on the fruits of the tropical tree Macaranga tanarius, (as shown in Figure. 3)[58]. Jeju Island, Korea (Angelica keiskei Ito) and Kangaroo Island, Australia (Lepidosperma spp., Acacia paradoxa D.C. and Myoporum insulare R. Br(family of Scrophulariaceae Juss) (Figure. 5)[46,64].Another tropical propolis type is the one originating from resin exuded by the flowers of different Clusia species found in Cuba and Venezuela $[65,66,67]$
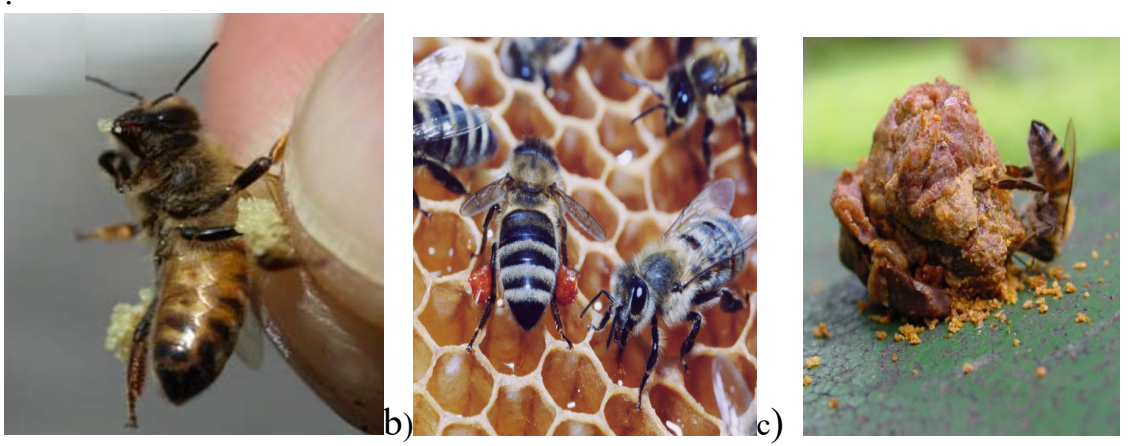

Figure 2. propolis collection by honeybees (role in beehive) and aspect of propolis after ollection by beekeeper.(a) honeybee with a piece of propolis on its leg. (b) propolis collector bee with propolis load on the corbicula;(c) Propolis after collection from the hive by beekeeper $[58,68]$.

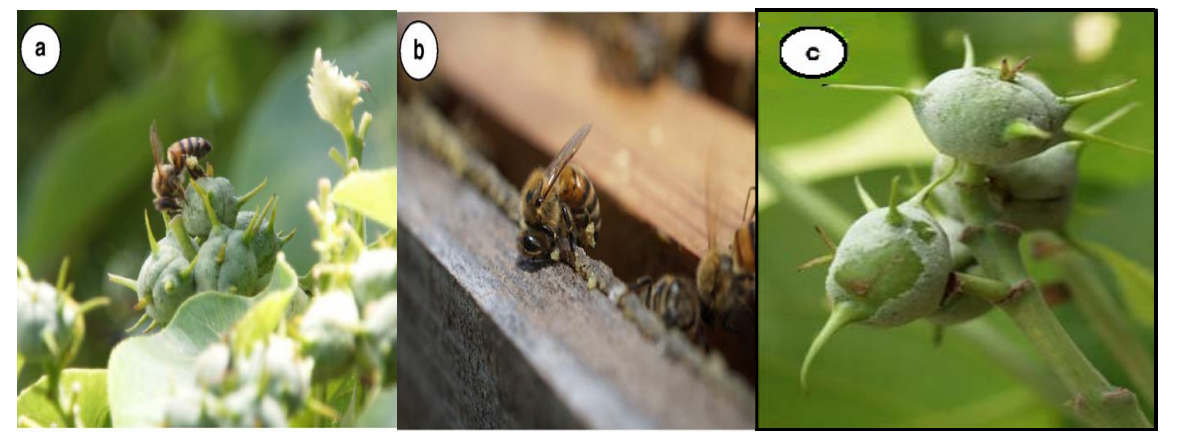

Figure 3. Photographs of a honeybee collecting the surface materials of $\mathrm{M}$. tanarius fruit to bring them back to its nest as propolis. a) a honeybee collecting the surface material of $M$. tanarius fruit; $b$ ) a honeybee attaching the propolis to the nest; c) surface material of $M$. tanarius fruit remaining after collection by honeybees [58]. 


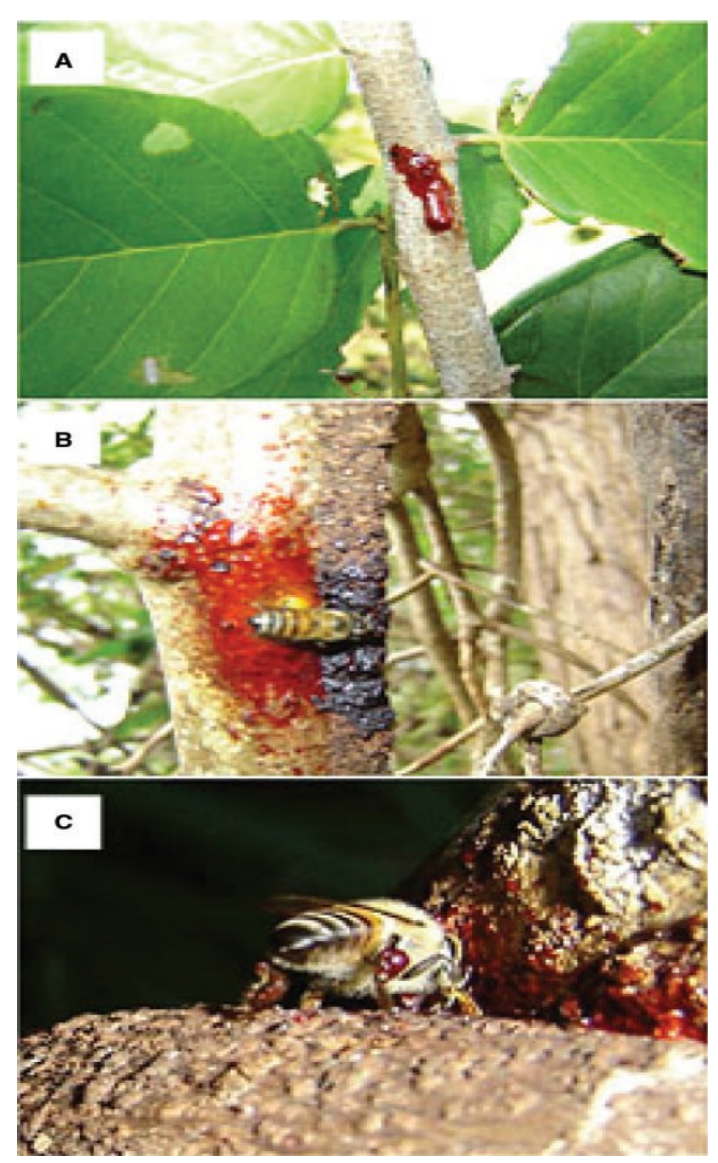

Figure 4.. Collection of propolis from reddish resinous exudates of D. ecastophyllum by africanized Apis mellifera. (A) Secrete reddish exudates from a hole in a branch of the tree. (B) Bee is collecting the reddish exudates. (C) The collected exudates passed to the hind leg to make propolis [59].

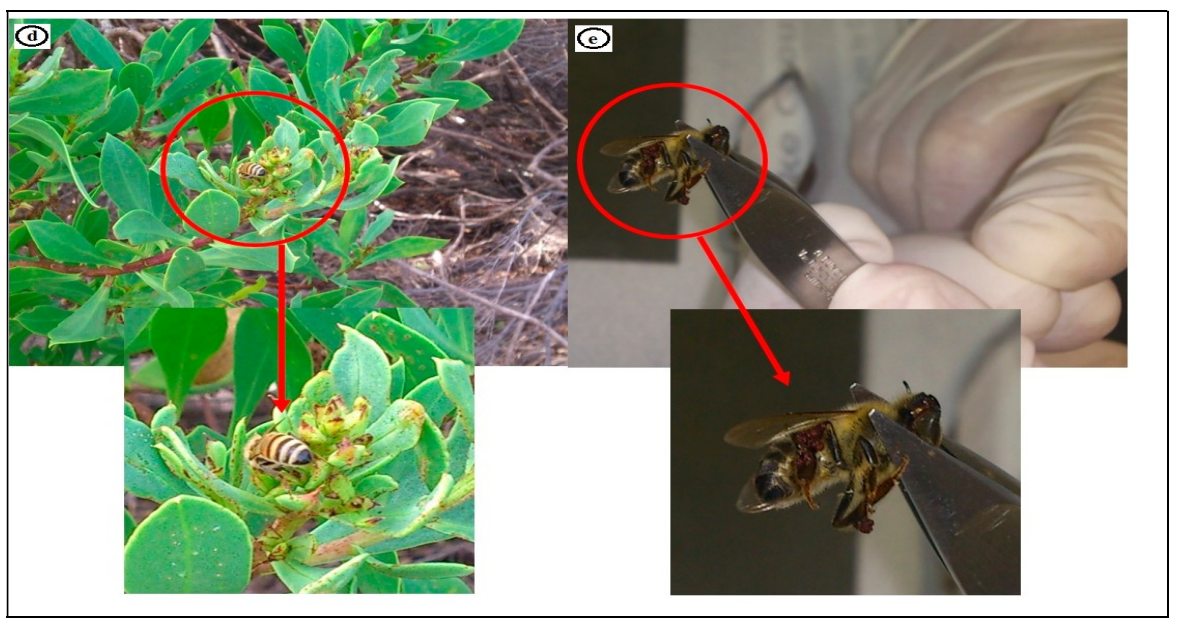

Figure. 5. (d) Propolis collection by bees from resinous leaves of Myoporum insulare; (e) Laboratory analysis of the bee legs with propolis collected from Myoporum insulare leaves surface [64] 
Table .1. propolis types: Geographic origin and plant source.

\begin{tabular}{|c|c|c|c|}
\hline $\begin{array}{l}\text { Propolis } \\
\text { type }\end{array}$ & Geographic origin & Plant source & References \\
\hline Poplar & $\begin{array}{l}\text { Europe, } \\
\text { North America, } \\
\text { non-tropic } \\
\text { regions of Asia, } \\
\text { China, New Zealand }\end{array}$ & Populus spp. & $\begin{array}{l}{[21,34,47,48} \\
, 49,50,51,52, \\
53,54] \\
69,70,71]\end{array}$ \\
\hline Green & Brazil & $\begin{array}{l}\text { Baccharis spp. } \\
\text { (B. dracunculifolia) } \\
\text { Hyptis divaricate } \\
\text { Dalbergia } \\
\text { ecastaphyllum }\end{array}$ & $\begin{array}{l}{[55,56,57,} \\
64,72] \\
{[73]} \\
{[55,72,74]}\end{array}$ \\
\hline $\begin{array}{l}\text { Red } \\
\text { propolis }\end{array}$ & Cuba, Brazil, Mexico & Dalbergia spp. & {$[57,59,60]$} \\
\hline $\begin{array}{l}\text { Mediterran } \\
\text { ean }\end{array}$ & $\begin{array}{l}\text { Sicily, Greece, Crete, } \\
\text { Gozo, Malta,Croatia } \\
\text { Algeria }\end{array}$ & $\begin{array}{l}\text { Cupressaceae } \\
\text { Populus spp. } \\
\text { and Ferula spp. }\end{array}$ & $\begin{array}{l}{[75,} \\
76,77,78]\end{array}$ \\
\hline & & $\begin{array}{l}\text { Populus spp. } \\
\text { Cistus spp. }\end{array}$ & $\begin{array}{l}{[79]} \\
{[80]}\end{array}$ \\
\hline Clusia & Cuba, Venezuela & Clusia spp. & $\begin{array}{l}{[19,65,66,67} \\
, 81] .\end{array}$ \\
\hline Pacific & $\begin{array}{l}\text { Pacific } \\
\text { region,Okinawa, } \\
\text { Taiwan, Indonesia) }\end{array}$ & $\begin{array}{l}\text { Macaranga tanarius } \\
\text { Angelica keskei (Miq.) } \\
\text { Koidz }\end{array}$ & $\begin{array}{l}{[58,61,62,63} \\
]\end{array}$ \\
\hline & Korea, Jeju Island & $\begin{array}{l}\text { Plumeria acuminata } \\
\text { W. T. Aiton, } P .\end{array}$ & [82] \\
\hline Australia & Hawaii, & $\begin{array}{l}\text { acutifolia Poir } \\
\text { Xanthorrhoea }\end{array}$ & $\begin{array}{l}{[83]} \\
{[17]}\end{array}$ \\
\hline $\begin{array}{l}\text { Kangaroo } \\
\text { Island }\end{array}$ & & Lepidosperma spp. & {$[46,64]$.} \\
\hline $\begin{array}{l}\text { "Canarian" } \\
\text { Propolis }\end{array}$ & Canary Islands & Unknown & {$[23,84]$} \\
\hline $\begin{array}{l}\text { "Chilean" } \\
\text { Propolis }\end{array}$ & Chile & $\begin{array}{l}\text { Quillaja saponaria, } \\
\text { Salix humboldtiana, } \\
\text { S babylonica, } \\
\text { Eucalyptus globules }\end{array}$ & {$[85,86]$} \\
\hline $\begin{array}{l}\text { Birch } \\
\text { propolis }\end{array}$ & Russia & Betula verrucosa Ehrh & {$[20,87]$} \\
\hline
\end{tabular}

One of the most important Subtropical propolis types turned out to be the so called Mediterranean propolis, which is characterized by the high concentration of diterpenics $[75,76,77,78,79]$. Its source belongs to the Cupressaceae family (Cupressus sepmervirens). In addition propolis from the Mediterranean region contains flavonoids, phenolic acid and its esters [ 88 ] . 
In Tunisia, where poplars are not always available, leaf exudates of some Cistus spp. act as propolis source [89], while in the Sonoran desert Ambrosia deltoidea and Encelia farinosa played this role [90,91]. In Algeria [92]., Iran, Ferula spp, Juniperus polycarpus [93], have been found to contribute to propolis as plant source, next to Populus spp [92,94], Thus support idea of direct impact of vegetation and environment on the compositions and biological activity of propolis[93].

Othewise, The composition of propolis differs greatly depending on its botanical origin. The measured compounds should be important from biological points of view [46].

\subsection{Biological activities of propolis}

The biological activities of propolis have been confirmed by numerous scientific studies, as shown in Table 3. Antimicrobial properties of all types of propolis are well documented by many researchers [95].against bacteria $[18,19,96]$, fungus $[97,98,99]$, virus $[23,100,101]$ and parasites [102].

\subsubsection{Antibacterial activity}

The most popular, well studied and documented activity of propolis is the antibacterial one $[45,81,101,103,104]$. As shown in Table $N$ mechanism of anti-bacterial activity of some active compound from propolis.

It was evidenced that the mechanism of action of propolis on bacterial cell is complex and a simple analogy cannot be made to the mode of action of any classic antibiotics. Direct antibacterial activity of propolis was attributed to differents mechanisms; Inhibition of cytoplasmic membrane function, disruption of membrane potential and energy production, inhibition of protein synthesis, inhibition of nucleic acid synthesis [19,105,106,107,108].

Propolis affects the permeability and structure of the cellular membrane of microorganism, thus mechanism is due to electrostatic-based intermolecular interaction positively charged groups of propolis compounds (positively charged groups:cationic moieties) and the bacterial surface (negatively charged: anionic sites). Thus causing damage of the cell walls and bacteria form [107], alteration of the physico-chemical properties of surface layer cells [108], disruption of membrane potential and bioenergetic status ( inhibition of adenosine triphosphate (ATP) production).

In addition, propolis extract inhibit biofilm formation [109]), and posses anti-quorum sensing activity [110], Recently, Wang and co workers [111] demonstrated that Australian propolis ethanol extract (APEE) possesse anti-planktonic, anti-biofilm and anti-adhesive activities against MRSA strains.

Otherwise, Vadillo-Rodríguez and collaborators 2021 suggested that initial mechanism of action of propolis resulting from interaction between different propolis components and bacterial cell wall structures. Presence of phenolic compounds and flavonoides are recognized for antimicrobial activity of propolis [112], Furthermore, phenylates flavonoids, is responsible for cell membrane damage, caused by lipophilic prenyl group. Synergistic activity between phenolic and other compounds was reported previously, by Castaldo [113] and recently, by Grecka [114]. Substances identified in propolis, such as pinocembrin, galangin, caffeic acid, ferulic acid, pinobanksin, benzyl ester, may act on the microbial membrane or cell wall site, causing functional and structural damages [19,105], constituents of propolis can interact with bacterial stucture by forming intramolecular hydrogen bonds that create 
hydrophobic interactions between the cell wall or membrane and propolis antimicrobial compounds [108].

It was reported by de Oliveira Dembogurski et al. 2018, that Artepillin C (3,5-diprenyl- $p$-coumaric acid, a prenylated derivative of pcoumaric acid $(p \mathrm{CA})$ ), obtained from Brazilian green propolis posses a strong antimicrobial activity against planktonic and biofilm cells. Also, Artepillin C in synergy with other $p$ CA derivatives is responsible for the antimicrobial effects [115]. Moreover, CAPE, an active component of propolis, is a competitive inhibitor of peptide deformylase, essential enzyme of $H$. pylori. CAPE can block interaction of substrate-active site with enzyme [116].

Table 2. mechanism of anti-bacterial activity of some active compound from propolis. Antibacterial potentials of propolis

Active Compound

pinocembrin, galangin, caffeic acid, ferulic acid, pinobanksin, benzyl ester

flavonone pinocembrin flavonol galangin, caffeic acid phenethyl ester,

Flavonoids

Cinnamic acid and its derivatives

Quercetin, naringenin.

Apigenin,

flavanone pinocembrin

(5,7-dihydroxyflavanone)

and its $3-\mathrm{OH}$ analogue flavonol galangin (3,5,7-trihydroxyflavon)

Caffeic acid

(3,4-dihydroxycinnamic acid) and its esters, volatile fractions with phenols
Mechanism of action

References

Functional and structural damages of cytoplasmic membrane or cell wall bacteria

$[19,105]$.

Inhibition of bacterial RNA polymerase

Formation of strong ligand complex with heavy atoms of bacteria's mettaloenzymes; metabolic perturbation in ion channels and phosphorylation/dephosphorylation reactions. loss

Damaging the cell membrane, inhibiting ATPases, cell division and biofilm formation. anti-quorum sensing activity .

Increase the permeability of inner bacterial membrane; inhibition of potential, decreasing the ATP production, membrane transport and mobility of bacteria

Prevention of formation of dental plaque. inhibition of GTF's (glucosyltransferase) ( enzymes considered as an important factor in the formation of dental plaque)

Degradation of cytoplasm membrane of bacteria; loss of potassium ions from cell membrane and autolysis bacterial cell.

$[18,119,12$ 0121,122 ] 
and/or terpenoids and chrysin

(5,7-dihydroxyflavone)

ethanolic propolis extract $i$

Inhibition of protein synthesis

[123].

Polyphenols of propolis

Formation of hydrogen and ionic bonds in microbial proteins; Alteration of function and structure of [106]. proteins.

phenylates flavonoids

lipophilic prenyl group cause cell membrane damage

Australian propolis

ethanol extract (APEE)

Disrupting cell structure; Inhibitory
planktonic bacterial cells and biofilm.

Cinnamoyloxy-mammeisin

Inhibition of bacteria adherence (MRSA) to host cells , disruption of biofilm development

Modification of physical properties of membrane bilayers

Flavonoides

(by changing phospholipids' gel-to-liquid crystal transition temperature).

Potassium loss from bacterial cells wall (damage of cytoplasmic membrane of bacteria )

flavone-based analogues

Inhibition of activity of DNA gyrase of E.coli (by intercalating into DNA).

guttiferone E, xanthochymol and oblongifolin B from ethanolic extracts of red (ERP) propolis, antimicrobial activity against multidrug-resistant bacteria (MDRB)

inhibited the biofilm formation of $S$. aureus $S$. [130]. epidermidis

Wink and co-workers 2008, 2015, demonstrated that polyphenols of propolis alter function and structure (three-dimensional structure 3D) of bacteria proteins. Such mechanism is due to formation of hydrogen and ionic bonds in microbial proteins by their interaction with polyphenols [106].

Flavonoids can form strong ligand complex with heavy atoms of bacteria's mettaloenzymes, such interaction probably are responsible of impairment in phosphorylation /dephosphorylation reactions that can lead to metabolic perturbation in ion channels and consequently, loss of viability of bacteria cells (bactericidial effect), [105,117]. It has been reported that propolis exhibits bacteriostatic activity against different bacterial strains and can be bactericidal in a high concentration [131],Vadillo-Rodríguez, [108] found that sub-bactericidal concentrations of propolis disturb and damge wall membrane and biofilm. Santos [132] , demonstrated that propolis extracts were effective in interfering with the formation of the C. pseudotuberculosis biofilm. Propolis also can affects cell division [27].

Tsuchiya and Iinuma, 2000, reported that the antimicrobial activity is potentially due to rutin, quercetin, naringenin. These compounds increase the permeability of the inner bacterial membrane and potential, decrease ATP production, membrane transport and mobility [28, 105]. Moreover, flavonoides modifiy physical properties of membrane bilayers by changing the phospholipids' gel-to-liquid crystal transition temperature to a more rigid, gel-like state [127]. In other hand,, galangin increase potassium loss 
rom bacterial cells wall, such mechanism is due to a direct damage to the cytoplasmic membrane of S. aureus [128].

Kim and Chung[28], reported that electron microscopic investigation of propolis- treated Bacillus cereus caused a structural damage by disintegration of the cell envelope, leakage of cytoplasmic and nuclear material from the cells. Other mechanism was described by Mirzoeva [105], EEP and some of its flavonoid components had negative effect on B. subtilis motility by inhibition of the membrane potential that can increased permeability of the membrane to ions.

It has been observed that the global synthesis of DNA and RNA cells was inhibited after addition of genistein. In a Study conducted by Verghese and co-workers [129], demonstrated that, flavone-based analogues, inhibit activity of DNA gyrase of E.coli through intercalating into DNA. Flavonone pinocembrin and the flavonol galangin, and caffeic acid phenethyl ester, whose action mechanism is based on the inhibition of bacterial RNA polymerase. The inhibition of bacterial RNA-polymerase by the components of propolis was probably due to the loss of their ability to bind to DNA [133].

Lin et al., [134]., investigated the effects of the flavonols myricetin, quercetin, kaempferol, and galangin on the inhibition of the binding activity of SSB (Single-stranded DNA (ssDNA)-binding protein) an important protein implicated in DNA replication, repair and recombination. They found that myricetin, was capable of inhibiting $P$. aeruginosa (PaSSB) activity. In addition, presence of aromatic acids and esters in propolis interferes with the division of Streptococcus agalactie through the formation of pseudo-multicellular forms, cytoplasm disorganization, protein synthesis inhibition and cell lysis Takaisi-Kikuni and Schilcher [123] [110]. In recent study conducted by de Souza [130],guttiferone E, xanthochymol and oblongifolin B obtained from ethanolic extracts of red (ERP) propolis, possess antimicrobial activity against multidrug-resistant bacteria (MDRB) They also inhibited the biofilm formation of $S$. aureus (ATCC 43300 and clinical isolate) and S. epidermidis (ATCC 14990 and clinical isolate) [130 ].

All investigation demonstrated that Gram positive microorganisms were sensitive to propolis, whereas, Gram negative ones were often resistant [19], Low sensitivity of Gram negative bacteria is that their outer membrane structure inhibits and/or retards the penetration of propolis. Also, propolis components could be destroyed in the bacterial suspension probably by hydrolytic enzymes released by the bacteria [135].

The antibacterial activities (Table 3.) of propolis were observed on aerobic and anaerobic Gram-positive (Staphylococcus aureus, S. aureus ATCC 25293, ATCC 29213,43300 [86,136,137,138],Bacillus cereus, Vancomycin resistant Enterococcus [137],Enterococcus faecalis, Micrococcus luteus, Nocardia asteroides, Staphylococcus epidermidis, S. epidermidis ATCC 14990 [138].Staphylococcus haemolyticus, Streptococcus faecalis, Streptococcus pneumioniae, Streptococcus pyogenes[139,140],Streptococcus haemolyticus, Streptococcus mutans, Actinomyces naeslundii, Lactobacillus acidophilus, and Peptostreptococcus micros) and Gram-negative (Aeromonas hydrophila, Brucella abortus, , Klebsiella pneumoniae, Pseudomonas aeruginosa, P. aeruginosa ATCC 27853, Escherichia 
coli, E.coli ATCC 35218[86,140,141] Neisseria gonorrhoeae [142], Enterobacter cloacae .Salmonella enteritidis[143], Salmonella typhi, Salmonella Typhimurium, Proteus mirabilis, Proteus vulgaris, Shigella dysenteriae, Porphyromonas gingivalis, Fusobacterium nucleatum, and Prevotella oralis), Lactobacillus acidophilus, Prevotella oralis, P. gingivalis, Fusobacterium nucleatum, Peptostreptococcus anaerobius, Actinomyces naeslundii and Veillonella parvula [144]. Porphyromona,Fusobacterium, Propionibacterium, Clostridium, Prevotella, Actinomyces and Bacteroides species [144,145,146].

Koo et al. in Brazil, found the antibacterial effect of propolis on Streptococcus mutans, Streptococcus sanguis. Such activity was due to inhibition of microbial glycosultransferase; enzyme implicated in pathogenicity of Streptococcus spp [147].

Otherwise, Dimov tested the efficacy of the water-soluble derivative (WSD) of propolis against experimental infections caused by Gram-negative pathogens (Klebsiella pneumoniae, Proteus vulgaris, Escherichia coli, Pseudomonas aeruginosa), [148].

In other study, Grochowski et al, (1985) in mice, study the effect of propolis ointment on experimental burns infection with P. aeruginosa. He found that the healing process in treated group was shorter than the control group (7- 13 days treated groups vs 14-18 days control group) [147]. Gregory et al (2002), found that the usage of skin cream based on propolis preparation, have a beneficial effects on the healing burn wounds [148]. Also, Santos and co-workers, 2008, evaluated the clinical efficacy of Brazilian propolis gel formulation in patients diagnosed with denture stomatitis [149].

In food application, numerous studies showed potential of propolis as a food preservative against pathogenic microorganisms such as Bacillus cereus, Staphylococcus aureus, Listeria monocytogenes, Enterococcus faecalis, Escherichia coli and Clostridium perfringenes [150,151, 152].

Extracts of propolis have been shown to enhance the efficacy of certain antibiotics (streptomycin, ampicillin, gentamycin, cloxacillin...) [105,153-156]. Additionally, Orsi et al., had studied the effect of combination of propolis and antibiotics (amoxicillin, ampicillin and cefalexin) against Salmonella Typhi. He reported that propolis extract diminished the resistance of the bacteria wall to antibiotics [157].

Therefore, Combination of propolis with antimicrobial drugs could potentiate the activities of known antibiotics, to reduced their marked side effects, and/or enhance the host immune system against microbial infection and to prevent emergence of resistant or multi-resistants strains [103]. 
Table 3. Anti-microbial activities of propolis against different bacteria

\section{Pathogens}

References

\section{Gram-positive bacteria}

Staphylococcus aureus, S.aureus Amme ATCC 29213, S.aureus ATCC 25923, S. aureus BAA ATCC 977, MRSA/NCTC ATCC 10442, Staphylococcus spp.; S.saprophyticus ATCC 15305,S. auricularis, S. capitis, S. epidermidis, S. haemolyticus, S. hominis, S. mutans, S. warnerii.

Streptococcus spp.; S. cricetus, S. faecalis, S.epidermis ATCC 14990, S.epidermis, S.pneumoniae ATCC 49619, S.pneumioniae, S.pyogenes ATCC 12344, S. pyogenes, S. $\beta$-haemolyticus, S. thermophilus ATCC 19258, S. mutans, S.sobrinus, S. agalactia ATCC 27956, S. viridians, S. oralis ATCC 35037.

Bacillus cereus, B. subtilis, B. subtilis ATCC 6051, B. mesentericus, Listeria. monocytogenes L. monocytogenes (ATCC, 19111)

Enterococcus spp.; Enterococcus faecalis, E. faecalis (ATCC 29212) E casseliflavus (ATCC 70032), VRE VanB ATCC 51299

Micrococcus luteus, Diplococcus pneumonae, Mycobacteria sp., Mycobacterium tuberculosis.

Actinomyces naeslundii, A. viscosus Lactobacillus acidophilus, Peptostreptococcus micros

\section{Gram negative bacteria}

Escherichia coli, E.coli (ATCC 25922), E.coli O157:H7 ATCC 35150, Pseudomonas aeruginosa, P. aeruginosa, (ATCC 27853), Helicobacter pylori, Proteus vulgaris, Shigella dysenteriae, S. flexneri ATCC 29903, Brucella abortus, Haemophilus influenzae ATCC 49747,Klebsiella pneumoniae, K. pneumoniae (ATCC 700603),(ATCC 13883), K. ozaemae, K. oxytoca ATCC 700324, Acinetobacter baumannii ATCC BAAm 747, Enterobacter cloacae ATCC700323, Yersinia enterocolitis ATCC 9610.

Salmonella spp (S. enteritidis, S.dublin,S. typhi, S. typhimurium: choleraesuis, S. choleraesuis ATCC 554,exneri, , paratyphi-A, paratyphi-B, typhi, gallinarum, pullorum, sonnei)

Corynebacterium spp; Corynebacterium diphtheria, C. pseudotuberculosis.

Capnocytophaga gingivalis, Porphyromonas anaerobius, Porphyromonas gingivalis.

Prevotella intermedia, Prevotella melaninogenica, Aeromonas hydrophila, Burkholderia cepacia ATCC 25416.

Fusobacterium nucleatum, Branhamella catarrhalis.

$[107,113,114,125,126,128,130$, $136,137,138]$

$[1,2,17,23,24,25,26,27,28,50,51$ $.60,127]$

$[3,4,5]$

[101]

$[96,113,105,117,120$,

$[107,114-121]$

$[139,140,144,145,146$,

$[107,116,117,120,48,152$, 153]

$[132,144,145,146,154,155]$ 


\section{The target pathogen and Synergy in antimicrobial activity}

The development of multidrug-resistant pathogens has been related to the occurrence of over- and under-dosage of antimicrobials [203,204].

In order to minimise the potential development of further antimicrobial resistance "The Copenhagen Recommendations: Report from the Invitational EU Conference on The Microbial Threat" were published (http://www.im.dk/publikationer/micro98/index.htm), which outlined the need for the development of "Novel principles for treating or preventing Infections in humans and animals". One strategy employed to overcome resistance mechanisms is the use of combinations of drugs and several plant extracts, which had exhibited synergistic activity against microorganisms [205]. . Among the natural sources of antimicrobial agents utilized to treat infectious diseases, propolis was exhaustively studied [27].

\section{Combination effect of propolis and antibiotic}

The synergistic effects of propolis and antibiotics are a new target for clinical research, in order to explore the benefits of this bee product [156].

Oksuz et al.,,2005, studied synergistic activity between ciprofloxacin and propolis in the treatment of experimental Staphylococcus aureus keratitis [157]. Other combination therapy in BALB/c mice salmonella infection (with Salmonella typhimurium), propolis and standard antibiotic efficacy of therapy was observed after 5 days of treatment [158].

Lin and colleagues. 2008 showed that the bactericidal action of ciprofloxacin was greatly enhanced by the sub-MIC addition of two polyphenols (kaempferol and quercetin) in [276]. Furthermore, propolis had synergistic effects with antibiotics acting on the bacterial wall and ribosome in vitro (chloramphenicol, tetracycline and neomycin) [160], in addition, EEP are most effective when combined with antibiotics that interfere with bacterial protein biosynthesis such as tetracycline, linezolid, chloramphenicol, gentamicin, tobramycin and netilmicin against MRSA and MSSA [160,161].

Recently, AL-Ani and co-workes[106], observed synergism between EEP and antibiotics that inhibit bacterial cell wall synthesis (vancomycin and oxacillin) against Streptococcus pyogenes, MRSA NCTC 10442, and VRE ATCC 51299. In addition, no synergistic activity of propolis and antibiotics acting on the DNA and folic acid (ciprofloxacin, norfloxacin and cotrimoxazole) was obtained [156]. In this same study, the synergism was investigated by using of sub minimal inhibitory concentration ( $1 / 2$ and $1 / 4$ of the MIC) for propolis (Brazilian, Bulgarian) and antibiotics, the authors suggested that such interactions can lead to bacteriostatic action towards Salmonella Typhi [162]. Also, synergistic or additive activity was observed after combinations of propolis extract with clarithromycin against Helicobacter pylori [164].

In other hand, Hamoud and co-workers, studies combination effects of phenolic monoterpenes (thymol) and vancomycin, such mixture of two compounds have synergistic effects, thymol preferentially affect the outer cell membrane of Gram-negative bacteria helping the traffic of vancomycin to peptidoglycan (site of action) [164].

The in vitro synergistic effect of kaempferol and quercetin, in combination with rifampicin, was demonstrated against clinical rifampicin-resistant methicillin-resistant $\mathrm{S}$. aureus (MRSA) isolates (Lin et al., 2008). Quercetin and kaempferol alone showed slight $\beta$-lactamase inhibition, but when combined with rifampicin, the complex exhibited good $\beta$-lactamase inhibitory effect. These compounds (quercetin/kaempferol) inhibit the catalytic activity of different bacterial topoisomerases (Bernard et al., 2008) and this might 
explain some of the synergistic activities between ciprofloxacin and quercetin/kaempferol (Lin et al., 2008) in [160].

Wang and his colleagues [111], demonstrated that Australian propolis ethanol extract (APEE) decrease $\beta$-lactamase activity and inhibit expression of specific drug-resistant protein; $P B P 2 a$ (penicillin binding protein 2a) in MRSA strains. Same authors suggested that combination of APEE with $\beta$-lactam antibiotics (ampicillin, methicillin.....), consequently, increasing therapeutic effect of antibiotic.

Kaempferol and its glycosides can also act synergistically with antibiotics (e.g. rifampicin, vancomycin, methicillin, erythromycin and clindamycin) against antibiotic-resistant bacteria (Lim et al., 2007; Xu et al., 2001) in [296], therefore suggesting that kaempferol could be used in combination with these drugs in cases of resistance [296].

\section{Conclusion}

Propolis, known in folk medicine since ancient times and possesses various biological properties including antimicrobial, antioxidant and anti-inflammatory.

Recently, the propolis has regained interest however, he chemical composition and biological activities of propolis depend mainly upon the local flora, the geographic region, and the climate. hence, further investigations and comprehensive qualitative and quantitative analyses of the specific propolis constituents and mechanism of action are needed for its usage.

Sforcin and Bankova [38] discussed the potential of propolis for the development of new drugs. They suggested that:

- More investigations will be needed in order to isolate and identify the main bioactive(s) compound(s).

- Development of clinical studies, to evaluate propolis samples activity in patients and/or in healthy individuals.

- Studies of interactions between propolis and other drugs.

Finally, as anti-infective agent propolis will constitutes an interesting natural alternative and complementatry products that merit more deeply investigation in academic, pharmaceutical research industry and medical practice to overcome problem of resistance to antibiotics.

Author Contributions: Conceptualization,S.A., B.M., literature search, methodology, investigation, resources,

S.A., B.M., original draft preparation, ., S.A., B.M., writing - review and editing.

Funding: This research received no external funding.

Institutional Review Board Statement: Not applicable.

Informed Consent Statement: Not applicable.

Data Availability Statement: Available data are presented in the manuscript.

Conflicts of Interest: The authors declare no conflict of interest 
References

1. WHO . National Action Plans and Monitoring and Evaluation, Surveillance, Prevention and Control 2015. 28p: 9789241509763 https://www.who.int/antimicrobial-resistance/global-action-plan/en/

2. WHO .World Health Organization. Related WHO publications and links on antimicrobial resistance. 2009. Available at: http://www.who.int/foodborne disease /resistance /publications /en /index.html.

3. Capita, R., and Alonso-Calleja, C. Antibiotic-Resistant Bacteria: A Challenge for the Food Industry Critical Reviews in Food Science and Nutrition, 2013,53,11-48.

4. Willyard C. The drug-resistant bacteria that pose the greatest health threats. Nature. 2017;543(7643):15. doi:10.1038/nature.2017.21550

5. Singh P, Holmen J. Multidrug-Resistant Infections in the Developing World. Pediatr Clin North Am. 2022;69(1):141-152. doi:10.1016/j.pcl.2021.09.003

6. Kong Q, Yang Y. Recent advances in antibacterial agents. Bioorg Med Chem Lett. 2021;35:127799. doi:10.1016/j.bmcl.2021.127799.

7. Rivera-Yañez N, Rivera-Yañez CR, Pozo-Molina G, et al. Effects of Propolis on Infectious Diseases of Medical Relevance. Biology (Basel).2021;10(5):428.. doi: 10.3390/biology10 050428

8. Fokt, H.; Pereira, A.; Ferreira, A. M.; Cunha A.; Aguiar, C. Current Research, Technology and Education Topics in Applied Microbiology and Microbial Biotechnology. Microbiology, 2010, 2, 481-493.

9. Herrmann, M., Nkuiya, B., Dussault, A.R. Innovation and antibiotic use within antibiotic classes: Market incentives and economic instruments. Resource and Energy Economics . 2013, 35, 582-598.

10. Rodríguez-Rojas, A., Rodríguez-Beltrán, J., Couce, A., Blázquez, J. Antibiotics and antibiotic resistance: A bitter fight against evolution. International Journal of Medical Microbiology ,2013, 303, 293- 297.

11. Marshall, B.M. and Levy, S,B. Food Animals and Antimicrobials: Impacts on Human Health Clinical Microbiology Review, 2011, 718-733.

12. Kalghatgi , S., Spina, C. S., Costello, J. C., Liesa, M., Morones-Ramirez, J. R., Slomovic, S., Molina, A., Shirihai, O.S., Collins, J. J. Bactericidal Antibiotics Induce Mitochondrial Dysfunction and Oxidative Damage in Mammalian Cells. Science Translational Medicine. 2013,5,192, abstract

13. Halliwell, B., Whiteman, M. Measuring reactive species and oxidative damage in vivo and in cell culture: how should you do it and what do the results mean? British Journal of Pharmacology. 2004, 142:231-255.

14. Halliwell, B. Oxidative stress and neurodegeneration: where are we now? Journal of neurochemistry, 2006.,97:1634-1658.

15. Farnsworth, N.R.; Bingel, A.S. New Natural Products and Plant Drugs with Pharmacological, Biological, or Therapeutic Activity, Springer, New York, 1997.

16. Mohamed, W.M. Phytochemical studies on the phenolics constituents of genus Acacia and its applications in industry. MSc thesis, Helwan University, Cairo, Egypt, October 2009. 
17. -Ghisalberti, E. L. Propolis: a review. Bee World. 1979, 60, 59-84.

18. Burdock, G.A. Review of the biological properties and toxicity of bee propolis. Food Chemical Toxicology, 1998, 36, 347-363.

19. Marcucci, M.C. Propolis: chemical composition, biological properties and therapeutic activity. Apidologie, 1995, 26, 83-99.

20. Bankova, V.; De Castro, S.L.; Marcucci, M.C. Propolis: recent advances in chemistry and plant origin. Apidologie. 2000, 31, 3-15.

21. Bankova, V. Recent trends and important developments in propolis research. Evidence Based Complementary and Alternative Medicine, 2005, 2, 29-32.

22. Bankova V, Popova M, Trusheva B, 2016. New emerging fields of application of propolis. Maced J Chem Chem Eng .2016.35(1):1-11. DOI: 10.20450/mjcce.2016.864

23. Kujumgiev, A.; Tsvetkova, I.; Serkedjieva, Y.; Bankova, V.; Christov, R.; Popov, S. Antibacterial, antifungal and antiviral activity of propolis from different geographic origins. Journal of Ethnopharmacology, 1999, 64, 235-240.

24. Kartal, M.; Yildiz, S.: Kaya, S.: Kurucu, S.: Topcu, G. Antimicrobial activity of propolis samples from to different regions of Anatolia. Journal of Ethnopharmacololgy, 2003, 86, 69-73.

25. Ugur, A.; Barlas, M.; Ceyhan, N.; Turkmen, V. Antimicrobial Effects of Propolis Extracts on Escherichia coli and Staphylococcus aureus Strains Resistant to Various Antibiotics and Some Microorganisms Journal of Medicinal Food, 2000, 3(4), 173-180.

26. Greenaway, W.; Scaysbrook, T.; Whatley, F. R.The composition and plant origins of propolis: A report of work at Oxford. Bee World, 1990, 71 (3), 107-118.

27. Kim, Y.; Chung, H. The effects of Korean propolis against foodborne pathogens and transmission electron microscopic examination. New Biotechnology, 2011, 28 (6), 713-718.

28. Silva, J.C.; Rodrigues, S.; Feás, X.; Estevinho, L.M. Antimicrobial activity, phenolic profile and role in the inflammation of propolis. Food and Chemical Toxicology, 2012, 50, 1790-1795.

29. Bufalo, M.C.; Figueiredo, A.S.; Sousa, J.P.B.; Candeias, J.M.G.; Bastos, J.K.; Sforcin, J.M. Anti-poliovirus activity of Baccharis dracunculifolia and propolis by cell viability determination and real-time PCR. Journal of Applied Microbiology, 2009, 107, 1669-1680.

30. Ota, C.; Unterkircher, C.; Fantinato, V.; Shimuzu, M.T. Antifungal activity of propolis on different species of Candida. Mycoses, 2001, 44, 375-378.

31. Sun, F.; Hayami, S.; Haruna, S.; Ogiri, Y.; Tanaka, K.; Yamada, Y.; Ikeda, K.; Yamada, H.; Sugimoto, H.; Kawai, N.; Kojo, S. In vivo antioxidative activity of propolis evaluated by the interaction with vitamin $\mathrm{C}$ and vitamin $\mathrm{E}$ and the level of lipid hydroperoxides in rats. Journal of Agricultural Food Chemistry. 2000, 48, 1462-1465.

32. Isla, M.I.; Moreno, M.I.N.; Sampietro, A.R.; Vattuone, M.A. Antioxidant activity of Argentina propolis extracts. Journal of Ethnopharmacololgy , 2001, 76, 165-170. 
33. Sforcin, J.M. Propolis and the immune system: a review. Journal of Ethnopharmacololgy, 2007, 113, 1-14.

34. Anjum SI, Ullah A, Khan KA, et al. Composition and functional properties of propolis (bee glue): A review. Saudi J Biol Sci. 2019;26(7):1695-1703. doi:10.1016/j.sjbs.2018.08.013

35. Bogdanov, S.; Bankova, V. Propolis: Origin, Production, Compostion. The propolis book, Bee product science, 2012, $1,1-15$.

36. Kuropatnicki, A. K.; Szliszka, E.; Krol, W.; Historical Aspects of Propolis Research in Modern Times Evidence-Based Complementary and Alternative Medicine, 2013, 1-11.

37. Abd El Hady, F. K.; Hegazi, A. G. Egyptian propolis, 2. Chemical composition, antiviral and anti-microbial activities of East Nile Delta propolis. Z. Naturforsch, 2002, 57c, 386-394.

38. Sforcin, J. M., Bankova, V. Propolis: Is there a potential for the development of new drugs? Journal of Ethnopharmacology, 2011, 133 (2), 253-260.

39. An interview with scientist-biochemist;Sergey Alekseevich Popravko. part 2: "'Russian Penicillin " 2013, http://en.popravko.com/parts.php?id=128.

40. Wollenweber, E.; Hausen, B.M.; Greenaway, W. Phenolic constituents and sensitizing properties of propolis, poplar balsam and balsam of Peru. Bulletin de Liaison - Groupe Polyphenols, 1990, 15, 112-120.

41. Popravko, S. A.; Gurevich, A. I.; Kolosov, M. N. Flavonoid components of propolis. Chemistry of Natural Products, 1969,5 (6), 397-401.

42. Blicharska N, Seidel V. Chemical Diversity and Biological Activity of African Propolis. Prog Chem Org Nat Prod. 2019;109:415-450. doi:10.1007/978-3-030-12858-6_3.

43. Bankova, V. Chemical diversity of propolis and problem of standardization. Journal Ethnopharmacology, 2005, 100, 114-117.

44. Salatino, A., Fernandes-Silva, C. C. , Righi, A. A ., Salatino. M. L.F. Propolis research and the chemistry of plant products. Natural. Product. Report, 2011, 28, 925-936.

45. Przybyłek, I.; Karpinski, M.T. Antibacterial Properties of Propolis. Molecules 2019, 24(11), 2047.https://doi.org/10.3390/molecules24112047

46. Bankova V, Popova M, Trusheva B. The phytochemistry of the honeybee. Phytochemistry. 2018;155:1-11. doi:10.1016/j.phytochem.2018.07.007

47. Lihong C; Sanguandeekul,R.; Fuxing,Z. ; Deowanish, S., Thapa, R., Wongsiri, S., Advances in propolis research and propolis industry in China. The journal of the Royal Institute of Thailand. 2009,1,136-150

48. Jiang X, Tian J, Zheng Y, et al. A New Propolis Type from Changbai Mountains in North-east China: Chemical Composition, Botanical Origin and Biological Activity. Molecules. 2019;24(7):1369. doi:10.3390/molecules24071369.

49. Popova, M. P.; Bankova, V. S.; Bogdanov, S.; Tsvetkova, I.; Naydenski, C.; Marcazzan, G. L.; Sabatini, A. G. Chemical characteristics of poplar type propolis of different geographic origin. Apidologie, 2007,38 (3), $306-311$.

50. Silici, S.; Kutluca, S. Chemical composition and antibacterial activity of propolis collected by three different races 
of honeybees in the same region. Journal of Ethnopharmacology, 2005, 99 (1), 69-73.

51. Silici, S.; Unlu, M.; Vardar-unlu, G. Antibacterial activity and phytochemical evidence for the plant origin of Turkish propolis from different regions. World Journal of Microbiology E Biotechnology, 2007, 23 (12), 1797-1803.

52. Vardar-unlu, G.; Silici, S.; Unlu, M. Composition and in vitro antimicrobial activity of Populus buds and poplar-type propolis. World Journal of Microbiology E Biotechnology, 2008, 24 (7), 1011-1017.

53. Guzelmeric, E., Ristivojević, P., Trifković, J., Dastan, T., Yilmaz, O., Cengiz, O., \& Yesilada, E.. Authentication of Turkish propolis through HPTLC fingerprints combined with multivariate analysis and palynological data and their comparative antioxidant activity. LWT - Food Science and Technology, 2018,87, 23-32

54. Ristivojević, P.; Dimkić, I.; Guzelmeric, E.; Trifković, J.; Knežević, M.; Berić, T.; Yesilada, E.; Milojković-Opsenica, D.; Stanković, S. Profiling of Turkish Propolis Subtypes: Comparative Evaluation of Their Phytochemical Compositions, Antioxidant and Antimicrobial Activities. LWT- Food Science and Technology, 2018, 95, 367-379. https://doi.org/10.1016/j.lwt.2018.04.063.

55. Boudourova-krasteva, G.; Bankova, V. S.; Sforcin, J. M.; Nikolova, N.; Popov, S. Phenolics from Brazilian propolis. Z. für Naturforschung, 1997, 52c, 676-679.

56. Tazawa, S.; Warashina, T.; Noro, T.; Miyase, T. Studies on the constituents of Brazilian propolis 1810 . Chemical $\mathcal{E}$ Pharmaceutical Bulletin, 1998, 46, (9), 1477-1479

57. Santos LM, Fonseca MS, Sokolonski AR, et al. Propolis: types, composition, biological activities, and veterinary product patent prospecting. J Sci Food Agric. 2020;100(4):1369-1382. doi:10.1002/jsfa.10024

58. Kumazawa, S.; Nakamura, J.; Murase, M.; Miyagawa, M.; Ahn, M. R.; Fukumoto, S. Plant origin of Okinawan propolis: honeybee behavior observation and phytochemical analysis. Naturwissenschaften, 2008, 95 (8), $781-786$.

59. Daugsch, A.; Moraes, C. S.; Fort, P.; Park, Y. K. Brazilian Red Propolis Chemical Composition and Botanical Origin. Evidence-based complementary and alternative medicine, 2008, 5 (4), 435-441

60. Trusheva, B.; Popova, M.; Bankova, V.; Simova, S.; Marcucci, M. C.; Miorin, P. L.; Pasin, F. D.; Tsvetkova, I. Bioactive constituents of Brazilian red propolis. Evidence-based complementary and alternative medicine, 2006, 3 (2), $249-254$.

61. Kumazawa, S.; Goto, H.; Hamasaka, T.; Fukumoto, S.; Fujimoto, T.; Nakayama, T. A new prenylated flavonoid from propolis collected in Okinawa, Japan. Bioscience Biotechnology and Biochemistry, 2004, 68 (1), $260-262$.

62. Chen, C. N.; Wu, C. L.; Shy, H. S.; Lin, J. K. Cytotoxic prenyl-flavanones from Taiwanese propolis. Journal of Natural Products, 2003, 66 (4), 503-506.

63. Huang, W. J.; Huang, C. H.; Wu, C. L.; Lin, J. K.; Chen, Y. W.; Lin, C. L.; Chuang, S. E.; Huang, C. Y.; Chen, C. N.; Propolin, G. A prenylflavanone, isolated from Taiwanese propolis, induces caspase dependent apoptosis in brain cancer cells. Journal of agricultural and food chemistry, 2005, 55 (18), 7366-7376.

64. Aminimoghadamfarouj N, Nematollahi A. Structure Elucidation and Botanical Characterization of Diterpenes from a Specific Type of Bee Glue. Molecules. 2017 ;22 (7):1185. doi:10.3390/molecules22071185.

65. Barberan, T.; Garcia-viguera, C.; Vit-olivier, P.; Ferreres, F.; Tomas-lorente, F. Phytochemical evidence for the botanical origin of tropical propolis from Venezuela. Phytochemistry, 1993, 34,191-196. 
66. Hernandez, I. M.; Fernandez, M. C.; Cuesta-rubio, O.; Piccinelli, A. L.; Rastrelli, L. Polyprenylated benzophenone derivatives from Cuban Propolis. Journal of Natural Products, 2005, 68 (6), 931-934.

67. Trusheva, B.; Popova, M.; Naydenski, H.; Tsvetkova, V.; Rodriguez, J. G.; Bankova, V. New polyisoprenylated benzophenones from Venezuelan propolis. Fitoterapia, 2004, 75 (7-8), 683-689.

68. Krell, R. Value-Added Products from beekeeping FAO Agricultural services bulletin. Food and Agriculture Organization of the United Nations Rome.1996.Chapter5-propolis.http://www.fao.org/docrep/w0076e Lw0076e00.htm\#con

69. Isidorov VA, Bakier S, Pirożnikow E, Zambrzycka M, Swiecicka I. Selective Behaviour of Honeybees in Acquiring European Propolis Plant Precursors. J Chem Ecol. 2016;42(6):475-485. doi:10.1007/s10886-016-0708-9

70. Bloor S, Catchpole O, Mitchell K, Webby R, Davis P. Antiproliferative Acylated Glycerols from New Zealand Propolis. J Nat Prod. 2019;82(9):2359-2367.doi: 10. 1021 /acs. jnatprod.8b00562

71. Yuan, M., Yuan, X.J., Pineda, M., Liang, Z.Y., He, J., Sun, S.W., Pan, T.L. and Li, K.P., 2020. A comparative study between Chinese propolis and Brazilian green propolis: metabolite profile and bioactivity. Food E Function, 11(3), pp.2368-2379.

72. Moise AR, Bobiş O. Baccharis dracunculifolia and Dalbergia ecastophyllum, Main Plant Sources for Bioactive Properties in Green and Red Brazilian Propolis. Plants (Basel). 2020;9(11):1619. Published 2020 Nov 21. doi:10.3390/plants9111619.

73. -Park, Y.K.; Alencar, S.M.; Aguiar, C.L.Botanical origin and chemical composition of Brazilian propolis. Journal of Agriculture and Food Chemistry, 2002, 50(9), 2502-2516.

74. -Alencar, S. M. Oldoni, T. L. C. Castro, M. L. Cabral, I.S.R., Costa-Neto, C.M.,Cury, J.A., Rosalen, P.L., Ikegaki, M, Chemical composition and biological activity of a new type of Brazilian propolis: red propolis. Journal of Ethnopharmacology, 2007, 113(2), 278-283.

75. Popova, M.; Graikou, K.; Bankova, V.; Chinou, I. Chemical composition of 10 selected samples of Mediterranean propolis 977626. Planta medica, 2008, 74 (9), 1100-1101.

76. Popova, M. P.; Graikou, K.; Chinou, I.; Bankova, V. S. GC-MS Profiling of Diterpene Compounds in Mediterranean Propolis from Greece. Journal of Agricultural and Food Chemistry, 2010, 58 (5), 3167-3176.

77. Saftić L, Peršurić Ž, Fornal E, Pavlešić T, Kraljević Pavelić S. Targeted and untargeted LC-MS polyphenolic profiling and chemometric analysis of propolis from different regions of Croatia. J Pharm Biomed Anal. 2019;165:162-172. doi:10.1016/j.jpba.2018.11.061

78. Kalogeropoulos, N.; Konteles, S.J.; Troullidou, E.; Mourtzinos, I.; Karathanos, V.T. Chemical composition, antioxidant activity and antimicrobial properties of propolis extracts from Greece and Cyprus. Food Chem. 2009, 116, 452-461 http: //dx. doi. Org/10.1016/j.foodchem.2009.02.060

79. Popova, M.; Trusheva, B.; Antonova, D.; Cutajar, S.; Mifsud, D.; Farrugia, C.; Tsvetkova, I.; Najdenski, H.; Bankova, V. The specific chemical profile of Mediterranean propolis from Malta. Food Chem. 2011, 126, 1431-1435.

80. Piccinelli AL, Mencherini T, Celano R, et al. Chemical composition and antioxidant activity of Algerian propolis. J Agric Food Chem.2013;61(21):5080-5088. Doi : 10. 1021 /jf 400779w 
81. Cardinault N, Cayeux MO, Percie du Sert P. La propolis : origine, composition et propriétés [Propolis: origin, composition and properties]. Phytotherapie (Paris). 2012;10(5):298-304. doi:10.1007/s10298-012-0733-y.

82. Shimomura K, Inui S, Sugiyama Y, et al. Identification of the plant origin of propolis from Jeju Island, Korea, by observation of honeybee behavior and phytochemical analysis. Biosci Biotechnol Biochem. 2012;76(11):2135-2138. doi:10.1271/bbb.120580.

83. Inui S, Hosoya T, Kumazawa S. Hawaiian propolis: comparative analysis and botanical origin. Nat Prod Commun. 2014;9(2):165-166.

84. Bankova V. S., Christov R. S., Tejera A. D. Lignans and other constituents of propolis from the canary islands. Phytochemistry. 1998;49(5):1411-1415. doi: 10.1016/S0031-9422(98)00108-3.

85. Barrientos L, Herrera CL, Montenegro G, et al. Chemical and botanical characterization of Chilean propolis and biological activity on cariogenic bacteria Streptococcus mutans and Streptococcus sobrinus. Braz J Microbiol. 2013;44(2):577-585. Published 2013 Oct 30. doi:10.15890/S1517-83822013000200038

86. Alvear M, Santos E, Cabezas F, Pérez-SanMartín A, Lespinasse M, Veloz J. Geographic Area of Collection Determines the Chemical Composition and Antimicrobial Potential of Three Extracts of Chilean Propolis. Plants (Basel). 2021;10(8):1543. Published 2021 Jul 28. doi:10.3390/plants10081543

87. Dezmirean DS, Paşca C, Moise AR, Bobiş O. Plant Sources Responsible for the Chemical Composition and Main Bioactive Properties of Poplar-Type Propolis. Plants (Basel). 2020;10(1):22. Published 2020 Dec 24. doi:10.3390/plants10010022

88. El-Guendouz S, Lyoussi B, Miguel MG. Insight on Propolis from Mediterranean Countries: Chemical Composition, Biological Activities and Application Fields. Chem Biodivers. 2019;16(7):e1900094. doi:10.1002/cbdv.201900094

89. Martos, I.; Cossentini, M.; Ferreres, F.; Tomas-barberan, F. A. Flavonoid composition of Tunisian honeys and propolis. Journal of agricultural and food chemistry, 1997, 45 (8), 2824-2829.

90. Alday E, Valencia D, Garibay-Escobar A, et al. Plant origin authentication of Sonoran Desert propolis: an antiproliferative propolis from a semi-arid region. Naturwissenschaften. 2019;106(5-6):25. Published 2019 May 8. doi:10.1007/s00114-019-1620-2.

91. Wollenweber, E.; Buchmann, S. L. Feral honey bees in the Sonoran desert: propolis sources other than polars (Populus spp.) 1714. Zeitschrift für Naturforschung, 1997, 52, 530-535.

92. Debbache-Benaida, N.; Atmani, D.; Atmani, D. Chemical analysis and biological activities of Populus nigra, flower buds extracts as source of propolis in Algeria. Ind. Crop. Prod. 2014, 53, 85-92. doi: 10.1016/j.indcrop.2013.12.018.

93. Afrouzan $\mathrm{H}$, Tahghighi A, Zakeri S, Es-haghi A. Chemical Composition and Antimicrobial Activities of Iranian Propolis. Iran Biomed J. 2018;22(1):50-65. doi: 10. 22 03 4/ibj.22.1.50.

94. Trusheva, B.; Todorov, I.; Ninova, M.; Najdenski, H.; Daneshmand, A.; Bankova, V. Antibacterial mono- and sesquiterpene esters of benzoic acids from Iranian propolis. Chemistry Central Journal, 2010, 4, 1-4. 
95. Veiga, R.S.; De Mendonça, S.; Mendes, P.B.; Paulino, N.; Mimica, M.J.; Lagareiro Netto, A.A.; Lira, I.S.; López, B.G.-C.; Negrão, V.; Marcucci, M.C. Artepillin C and phenolic compounds responsible for antimicrobial and antioxidant activity of green propolis and Baccharis dracunculifolia DC. J. Appl. Microbiol. 2017;122(4):911-920.doi: 10. 1111 jam.13400.

96. Sforcin, J.M.; Fernandes Jr. A.; Lopes, C.A.M.; Bankova, V.; Funari, S.R.C. Seasonal effect on Brazilian propolis antibacterial activity. Journal of Ethnopharmacology, 2000, 73, 243-249

97. Cafarchia, C.; De Laurentis, N.; Milillo, M.A.; Losacco, V.; Puccini, V. Antifungal activity of Apulia region propolis. Parassitologia, 1999, 41, 587-590.

98. Fernandes, F. F.; Dias, A. L. T.; Ramos, C. L.; Ikegaki, M.; De Siqueira, A. M.; Franco, M. C. The “in vitro" Antifungal Activity Evaluation of Propolis G12 Ethanol extract on Cryptococcus neoformans. Journal of the Institute of Tropical Medicine of São Paulo , 2007, 49(2), 93-95.

99. Sforcin, J.M.; Fernandes Jr. A.; Lopes, C.A.M.; Funari, S.R.C.; Bankova, V. Seasonal effect of Brazilian propolis on Candida albicans and Candida tropicalis. Journal of Venomous Animals and Toxins, 2001, 7, 139-144.

100. Gekker, G.; Hu, S.; Spivak, M.; Lokensgard, J.R.; Peterson, P.K. Anti-HIV-1 activity of propolis in CD4(+) lymphocyte and microglial cell cultures. Journal of Ethnopharmacology, 2005, 102, 158-163.

101. Drago, L.; De Vecchi, E. In vitro antimicrobial activity of a novel propolis formulation (actichelated propolis). Journal of Applied Microbiology, 2007, 103, 1914-1921

102. Gressler, L.T.; Da Silva, A.S.; Machado, G.; Dalla Rosa, L.; Dorneles, F.; Gressler, L.T.; Oliveira, M.S.; Zanette, R.A.; de Vargas, A.C.; Monteiro, S.G. Susceptibility of Trypanosoma evansi to propolis extract in vitro and in experimentally infected rats. Research Veterinary Science., 2012, 93(3), 1314-7.

103. Bosio, K.; Avanzini, C.; D’Avolio, A.; Ozino, O.; Savoia, D. In vitro activity of propolis against Streptococcus pyogenes. Letert. Appiedl. Mricrobiology., 2000, 31, 174-177.

104. Giampieri F, Quiles JL, Cianciosi D, et al. Bee Products: An Emblematic Example of Underutilized Sources of Bioactive Compounds. J Agric Food Chem. 2022;10.1021/acs.jafc.1c05822. doi:10.1021/acs.jafc.1c05822.

105. Mirzoeva, O.K.; Grishanin, R.N.; Colder, P.C. Antimicrobial action of propolis and some of its components: the effect on growth, membrane potential and motility of bacteria. Microbiological Research, 1997, 52, 239-246

106. Al-Ani I, Zimmermann S, Reichling J, Wink M. Antimicrobial Activities of European Propolis Collected from Various Geographic Origins Alone and in Combination with Antibiotics. Medicines (Basel). 2018;5(1):2.doi:10.3390/medicines501000.

107. de Campos JV, Garrido Assis OB, Bernardes-Filho R Atomic force microscopy evidences of bacterial cell damage caused by propolis extracts on E. coli and S. aureus. Food Sci Technol. 2020, 40(1):55-61, https://doi.org/10.1590/fst.32018.

108. Vadillo-Rodríguez V, Cavagnola MA, Pérez-Giraldo C, Fernández-Calderón MC. A physico-chemical study of the interaction of ethanolic extracts of propolis with bacterial cells. Colloids Surf B Biointerfaces. 2021;200:111571. doi:10.1016/j.colsurfb.2021.111571

109. Stähli A, Schröter H, Bullitta S, et al. In Vitro Activity of Propolis on Oral Microorganisms and Biofilms. Antibiotics (Basel). 2021;10(9):10 45.doi:10.3390 /antibiotics10091045. 
110. Vasconcelos NG, Croda J, Simionatto S. Antibacterial mechanisms of cinnamon and its constituents: A review. Microb Pathog. 2018;120:198-203.doi:10.1016/j.micpath. 2018.04.036.

111. Wang F, Liu H, Li J, Zhang W, Jiang B, Xuan H. Australian propolis ethanol extract exerts antibacterial activity against methicillin-resistant Staphylococcus aureus by mechanisms of disrupting cell structure, reversing resistance, and resisting biofilm. Braz J Microbiol. 2021;52(4):1651-1664. doi:10.1007/s42770-021-00547-7

112. Huang S, Zhang CP, Wang K, Li GQ, Hu FL. Recent advances in the chemical composition of propolis. Molecules. 2014;19(12):19610-19632.doi:10. 3390/ molecules 191219610.

113. Castaldo, S.; Capasso, F. Propolis, an old remedy used in modern medicine. Fitoterapia, 2002, 73, s1-6.

114. Grecka K, Szweda P. Synergistic Effects of Propolis Combined with 2-Phenoxyethanol and Antipyretics on the Growth of Staphylococcus aureus. Pharmaceutics. 2021;13(2):215. doi:10.3390/pharmaceutics13020215

115. Shahinozzaman M, Basak B, Emran R, Rozario P, Obanda DN. Artepillin C: A comprehensive review of its chemistry, bioavailability, and pharmacological properties. Fitoterapia. 2020;147:104775. doi:10.1016/j.fitote.2020.104775

116. Cui, K., Lu, W., Zhu, L., Shen, X., Huang, J. 2013. Caffeic acid phenethyl ester (CAPE), an active component of propolis, inhibits Helicobacter pylori peptide deformylase activity. Biochemical Biophysical Research Communication, 2013, 435, 289-294.

117. Farnesi, A.P.; Aquino-Ferreira, R.; De Jong, D.; Bastos, J.K.; Soares, A.E.E. Effects of stingless bee and honey bee propolis on four species of bacteria. Genetics Molecular Research, 2009, 8, 635-640.

118. Koo H, Rosalen PL, Cury JA, Park YK, Bowen WH. Effects of compounds found in propolis on Streptococcus mutans growth and on glucosyltransferase activity. Antimicrob Agents Chemother. 2002;46(5):1302-1309. doi:10.1128/AAC.46.5.1302-1309.2002.

119. Viuda-Martos M, Ruiz-Navajas $Y$, Fernández-López J, Pérez-Alvarez JA. Functional properties of honey, propolis, and royal jelly. J Food Sci. 2008;73(9):R117-R124. doi:10.1111/j.1750-3841.2008.00966.x.

120. Pepeljnjak S, Jalsenjak I, Maysinger D. Flavonoid content in propolis extracts and growth inhibition of Bacillus subtilis. Pharmazie. 1985;40(2):122-123.

121. Bankova V, Christov R, Kujumgiev A, Marcucci MC, Popov S. Chemical composition and antibacterial activity of Brazilian propolis. Z Naturforsch C J Biosci. 1995;50(3-4):167-172. doi:10.1515/znc-1995-3-402.

122. Afolayan AJ, Meyer JJ. The antimicrobial activity of 3,5,7-trihydroxyflavone isolated from the shoots of Helichrysum aureonitens. J Ethnopharmacol. 1997;57(3):177-181. doi:10.1016/s0378-8741(97)00065-2

123. Takaisi-Kikuni NB, Schilcher H. Electron microscopic and microcalorimetric investigations of the possible mechanism of the antibacterial action of a defined propolis provenance. Planta Med. 1994;60(3):222-227. doi:10.1055/s-2006-959463

124. Raghukumar R, Vali L, Watson D, Fearnley J, Seidel V. Antimethicillin-resistant Staphylococcus aureus (MRSA) activity of 'pacific propolis' and isolated prenylflavanones. Phytother Res. 2010;24(8):1181-1187. doi:10.1002/ptr.3096

125. Wang F, Liu H, Li J, Zhang W, Jiang B, Xuan H. Australian propolis ethanol extract exerts antibacterial activity against methicillin-resistant Staphylococcus aureus by mechanisms of disrupting cell structure, reversing resistance, and resisting biofilm. Braz J Microbiol. 2021;52(4):1651-1664. doi:10.1007/s42770-021-00547-7 
126. da Cunha MG, de Cássia Orlandi Sardi J, Freires IA, Franchin M, Rosalen PL. Antimicrobial, anti-adherence and antibiofilm activity against Staphylococcus aureus of a 4-phenyl coumarin derivative isolated from Brazilian geopropolis. Microb Pathog. 2020;139:103855.

127. Gutierrez J, Bakke A, Vatta M, Merrill AR. Plant Natural Products as Antimicrobials for Control of Streptomyces scabies: A Causative Agent of the Common Scab Disease. Front Microbiol. 2022;12:833233. doi:10.3389/fmicb.2021.833233

128. Cushnie TP, Hamilton VE, Chapman DG, Taylor PW, Lamb AJ. Aggregation of Staphylococcus aureus following treatment with the antibacterial flavonol galangin. J Appl Microbiol. 2007;103(5):1562-1567. doi:10.1111/j.1365-2672.2007.03393.x

129. Verghese J, Nguyen T, Oppegard LM, Seivert LM, Hiasa H, Ellis KC. Flavone-based analogues inspired by the natural product simocyclinone D8 as DNA gyrase inhibitors. Bioorg Med Chem Lett. 2013;23(21):5874-5877. doi:10.1016/j.bmcl.2013.08.094.

130. de Souza Silva T, Silva JMB, Braun GH, et al. Green and Red Brazilian Propolis: Antimicrobial Potential and Anti-Virulence against ATCC and Clinically Isolated Multidrug-Resistant Bacteria. Chem Biodivers. 2021;18(8):e2100307. doi:10.1002/cbdv.202100307.

131. Drago L, Mombelli B, De Vecchi E, Fassina MC, Tocalli L, Gismondo MR. In vitro antimicrobial activity of propolis dry extract [published correction appears in J Chemother 2001 Feb;13(1):102]. J Chemother. 2000;12(5):390-395. doi:10.1179/joc.2000.12.5.390

132. Santos LM, Rodrigues DM, Kalil MA, et al. Activity of Ethanolic and Supercritical Propolis Extracts in Corynebacterium pseudotuberculosis and Its Associated Biofilm. Front Vet Sci. 2021;8:700030. doi:10.3389/fvets.2021.700030

133. Simúth J, Trnovský J, Jeloková J. Inhibition of bacterial DNA-dependent RNA polymerases and restriction endonuclease by UV-absorbing components from propolis. Pharmazie. 1986;41(2):131-132.

134. Lin ES, Luo RH, Huang CY. A Complexed Crystal Structure of a Single-Stranded DNA-Binding Protein with Quercetin and the Structural Basis of Flavonol Inhibition Specificity. Int J Mol Sci. 2022;23(2):588. doi:10.3390/ijms23020588

135. Sforcin JM. Biological Properties and Therapeutic Applications of Propolis. Phytother Res. 2016;30(6):894-905. doi:10.1002/ptr.5605

136. Krol, W.; Scheller, S.; Shani, J.; Pietsz, G.; Czuba, Z. Synergistic effect of ethanol extract of propolis and antibiotics in the growth of Staphylococcus aureus. Drug Research., 1993, 43, 607- 609.

137. Kilic, M.; Baysallar, B.; Besirbelliolu, B.; Salih, K.; Sorkun, K.; Tanyuksel, M. In vitro antimicrobial activity of propolis against methicillin-resistant Staphylococcus aureus and vancomycin resistant Enterococcus faecium. Annals of Microbiology, 2005, 55 (2), 113-117.

138. de Souza Silva T, Silva JMB, Braun GH, et al. Green and Red Brazilian Propolis: Antimicrobial Potential and Anti-Virulence against ATCC and Clinically Isolated Multidrug-Resistant Bacteria. Chem Biodivers. 2021;18(8):e2100307. doi:10.1002/cbdv.202100307

139. Santos FA, Bastos EM, Uzeda M, et al. Antibacterial activity of Brazilian propolis and fractions against oral anaerobic bacteria. J Ethnopharmacol. 2002;80(1):1-7. doi:10.1016/s0378-8741(02)00003-x 
140. Grange JM, Davey RW. Antibacterial properties of propolis (bee glue). J R Soc Med. 1990;83(3):159-160.

141. da Cruz Almeida ET, da Silva MCD, Oliveira JMDS, et al. Chemical and microbiological characterization of tinctures and microcapsules loaded with Brazilian red propolis extract. J Pharm Anal. 2017;7(5):280-287. doi:10.1016/j.jpha.2017.03.004.

142. Vică ML, Glevitzky I, Glevitzky M, Siserman CV, Matei HV, Teodoru CA. Antibacterial Activity of Propolis Extracts from the Central Region of Romania against Neisseria gonorrhoeae. Antibiotics (Basel). 2021;10(6):689. doi: 10. 3390/ antibiotics 10060689.

143. Bonvehí JS, Gutiérrez AL. The antimicrobial effects of propolis collected in different regions in the Basque Country (Northern Spain). World J Microbiol Biotechnol. 2012;28(4):1351-1358. doi:10.1007/s11274-011-0932-y

144. Zulhendri F, Felitti R, Fearnley J, Ravalia M. The use of propolis in dentistry, oral health, and medicine: A review. J Oral Biosci. 2021;63(1):23-34. doi:10.1016 /j.job .2021.01. 001

145. Siheri, W.; Alenezi, S.; Tusiimire, J.; Watson, D. G. The Chemical and Biological Properties of Propolis. In Bee Products.:Chemical and Biological Properties; Springer International Publishing: Cham, Switzerland, 2017 ; pp 137-178.

146. Bapat S, Nagarajappa R, Ramesh G, Bapat K. Effect of propolis mouth rinse on oral microorganisms - a randomized controlled trial. Clin Oral Investig. 2021;25(11):6139-6146. doi:10.1007/s00784-021-03913-9.

147. Koo, H. . Cury, J. A. Rosaleu P. L and. Park, Y. K “Effects of Propolis from Two Different Regions of Brazil on Oral Microorganisms," Journal of Dental Research, 1998; 77; 1157.

148. Dimov V, Ivanovska N, Bankova V, Popov S. Immunomodulatory action of propolis: IV. Prophylactic activity against gram-negative infections and adjuvant effect of the water-soluble derivative. Vaccine. 1992;10(12):817-823. doi:10.1016/0264-410x(92)90043-j

149. Tugba Degirmencioglu H, Guzelmeric E, Yuksel PI, Kırmızıbekmez H, Deniz I, Yesilada E. A New Type of Anatolian Propolis: Evaluation of Its Chemical Composition, Activity Profile and Botanical Origin. Chem Biodivers. 2019;16(12):e1900492. doi:10.1002/cbdv.201900492

150. Fonseca AMV, Sampaio GHL, Araujo WP, et al. Photodynamic Therapy With Propolis: Antibacterial Effects on Staphylococcus aureus, Streptococcus mutans and Escherichia coli Analysed by Atomic Force Microscopy. J Lasers Med Sci. 2020;11(Suppl 1):S107-S112. doi:10.34172/jlms.2020.S17

151. Al-Waili N. Mixing two different propolis samples potentiates their antimicrobial activity and wound healing property: A novel approach in wound healing and infection. Vet World. 2018;11(8):1188-1195. doi:10.14202/vetworld.2018.1188-1195

152. Boulechfar S, Zellagui A, Asan-Ozusaglam M, et al. Chemical composition, antioxidant, and antimicrobial activities of two essential oils from Algerian propolis.. Z Naturforsch C J Biosci. 2021;10.1515/znc-2021-0028. doi:10.1515/znc-2021-0028

153. Lavigne JP, Ranfaing J, Dunyach-Rémy C, Sotto A. Synergistic Effect of Propolis and Antibiotics on Uropathogenic Escherichia coli. Antibiotics (Basel). 2020;9(11):739.. doi:10.3390/antibiotics9110739 
154. Rojas Hernandez NM, Candelario M, Olivares E. Antimicrobial activity of propolis against representatives of the genus Mycobacterium. Revista Biologia (Habana). 1993;7 :69-75.

155. Scheller S, Dworniczak S, Waldemar-Klimmek K, Rajca M, Tomczyk A, Shani J. Synergism between ethanolic extract of propolis (EEP) and anti-tuberculosis drugs on growth of mycobacteria. Z Naturforsch C J Biosci. 1999;54(7-8):549-553. doi:10.1515/znc-1999-7-814.

156. Orsi, R.O., Fernandes, A., Bankova, V., Sforcin, J.M. The effects of Brazilian and Bulgarian propolis in vitro against Salmonella Typhi and their synergism with antibiotics acting on the ribosome. Natural Product Research, 2012, $\underline{26}(\underline{5}), 430-437$.

157. Oksuz, H.; Duran, N.; Tamer, C.; Cetin, M.; Silici, S. Effect of propolis in the treatment of experimental Staphylococcus aureus keratitis in rabbits. Ophtalmic Research, 2005, 37, 328-334.

158. Kalia P, Kumar NR, Harjai K. Studies on the therapeutic effect of propolis along with standard antibacterial drug in Salmonella enterica serovar Typhimurium infected BALB/c mice. BMC Complement Altern Med. 2016;16(1):485. doi:10.1186/s12906-016-1474-5

159. Daglia, M., 2012. Polyphenols as antimicrobial agents .Current Opinion in Biotechnology. 23:174-181.

160. Wojtyczka RD, Dziedzic A, Idzik D, et al. Susceptibility of Staphylococcus aureus clinical isolates to propolis extract alone or in combination with antimicrobial drugs. Molecules. 2013;18(8):9623-9640.. doi:10.3390/molecules18089623

161. Orsi, R.O.; Sforcin, J.M.; Funari, S.R.C.; Junior, A.F.; Bankova, V. Synergistic Effect of Propolis and Antibiotics on the Salmonella TYPHI. Brazilian Journal of Microbiology, 2006, 37, 108-112

162. Nostro A, Cellini L, Di Bartolomeo S, Cannatelli MA, Di Campli E,Procopio F, Grande R, Marzio L, Alonzo V. Effects of combining extracts (from propolis or Zingiber officinale) with clarithromycin on Helicobacter pylori. Phytotherapy Research, 2006,20(3),187-190

163. Hamoud R, Zimmermann S, Reichling J, Wink M. Synergistic interactions in two-drug and three-drug combinations (thymol, EDTA and vancomycin) against multi drug resistant bacteria including E. coli. Phytomedicine. 2014;21(4):443-447. doi:10.1016 /j.phymed .2013.10.016

164. Calderón-Montaño JM, Burgos-Morón E, Pérez-Guerrero C, López-Lázaro M. A review on the dietary flavonoid kaempferol. Mini Rev Med Chem. 2011;11(4):298-344. doi:10.2174/138955711795305335 